\title{
Tick-Borne Rickettsial Pathogens in Rodents from Mexico
}

\author{
Carolina G. Sosa-Gutiérrez¹, Margarita Vargas², Javier Torres' ${ }^{1}$, Guadalupe Gordillo-Pérez ${ }^{1}$ \\ ${ }^{1}$ Unidad de Investigación Médica de Enfermedades Infecciosas y Parasitarias, Hospital de Pediatría, \\ Centro Médico Nacional Siglo XXI, Instituto Mexicano del Seguro Social, Mexico City, Mexico \\ ${ }^{2}$ Facultad de Agrobiología, Universidad Michoacana de San Nicolas de Hidalgo, Uruapan, México \\ Email: mcarososagtz@yahoo.com.mx, lugope2@yahoo.com.mx
}

Received 2 July 2014; revised 20 August 2014; accepted 5 September 2014

Copyright (C) 2014 by authors and Scientific Research Publishing Inc.

This work is licensed under the Creative Commons Attribution International License (CC BY). http://creativecommons.org/licenses/by/4.0/

(c) (i) Open Access

\section{Abstract}

Tick-Borne Rickettsial Diseases (TBRD) are emerging zoonotic diseases, and a problem of human health and veterinary medication. The distribution of these diseases is related to the distribution of vector. The presence of pathogens in the host is a risk indicator of population exposure to these areas. A total of 478 tissues samples from rodents, A. phagocytophilum 18 (3.7\%), E. canis 47 (9.8\%), Rickettsia rickettsii 18 (3.7\%) and E. chaffeensis 19 (3.9\%) were detected using speciesspecific PCR assay. It is the first report in Mexico the presence of rodents infected with $A$. phagocytophilum and $E$. chaffeensis. The rodent Peromyscus spp. were the most commonly prevalent host of infection for all the bacteria's. We have to consider as host of TBRD transmitter and provide a useful contribution to understanding their epidemiology. The health sector should be considered all the fevers of unknown causes in humans and animals in Mexico as infections by these vector-borne rickettsial pathogens.

\section{Keywords}

Anaplasma phagocytophilum, Ehrlichia chaffeensis, Rickettsia rickettsii, Ehrlichia canis, Rodents

\section{Introduction}

Tick-borne rickettsial diseases (TBRD) are zoonosis caused by Anaplasma phagocytophilum, Rickettsia rickettsii, Ehrlichia chaffeensis and E. canis. These pathogens are maintained in natural cycles involving wild mammals and hard-bodied (Ixodid) ticks. The epidemiologies of these diseases reflect the geographic distribution and seasonal activities of the vectors and reservoirs and the human behavior that place persons at risk for attachment and subsequent infection [1] [2]. TBRD are common occurrences in the medical and veterinary clinical setting, 
affecting domestic animals and humans, who has increased in recent years; gaining more attention from physicians and veterinarians [3]. The distribution of these diseases is related to the distribution of vector. The presence of pathogens in the vector and their host is a risk indicator of population exposure to these areas. In United States, Mexico and others countries, rodents (Peromyscus spp.) and white-tailed deer (Odocoileus virginianus) are reservoirs of Ehrlichia, Anaplasma and Borrelia spp. [4]-[6]. Early signs and symptoms of these illnesses are nonspecific, and therefore misdiagnosis and failure to treat have unfortunate and sometimes tragic outcomes [7]. The clinical featuring are similar, there are two weeks after the tick bite, have spiking fevers, chills, headache and myalgia; furthermore nausea, vomiting, anorexia and diarrhea. The fatality rate reported in patients without treatment is between $5 \%-25 \%$, and $1 \%$ to A. phagocytophilum [1] [8].

Many vector-borne diseases are zoonoses caused by pathogens having rodents as their natural host. Because the humans are not part of the natural transmission cycle, they are only incidentally infected. Zoonosis usually persists in nature in silent transmission cycles between vectors and rodent host, going undetected unless they spill over and infect the human population [9].

We previously reported the detection of tick-borne pathogens in ticks like A. phagocytophilum, E. chaffeensis, $E$. canis and $R$. rickettsii in 19 states of Mexico, and frequency of $B$. burgdorferi in ticks and small mammals from Mexico [6] [10]. Screening their host for disease-causing pathogens using molecular epidemiological tools provides useful data on the distribution and prevalence of tick-borne pathogens [11]. The presence of tick-borne pathogens, including A. phagocytophilum, E. chaffeensis, E. canis and R. rickettsii in rodents, has not yet to be determined by molecular tools in Mexico.

The purpose for this study was to provide a disease risk assessment for tick-borne rickettsial pathogens in rodents based on their potential exposure to ticks and theses pathogens that may affect human and animal health in Mexico.

\section{Material and Methods}

\subsection{Samples Collection}

During 2006 through 2012, a total of 491 rodents belonging to 12 genera and 22 species were collected using Sherman traps ( 3 ” $\times 5$ " $\times$ 9" folding traps); in 31 sites including Nationals parks, Eco-tourism parks, and recreational sites to population throughout 11 states of Mexico and were selected for assessment of tick-borne pathogens (Figure 1). All the rodents were euthanized and handled, accordance with approved protocol (R-2012-785069) of National Commission of Research and Bioethics. After blood samples were taken, one ear was dissected and then the abdominal cavity was opened aseptically, and spleen, liver and heart tissue samples were collected.

\subsection{DNA Preparation}

For extraction of 491 samples, PCR-amplifiable DNA, were taken different tissues of mice (spleen, ear or heart)

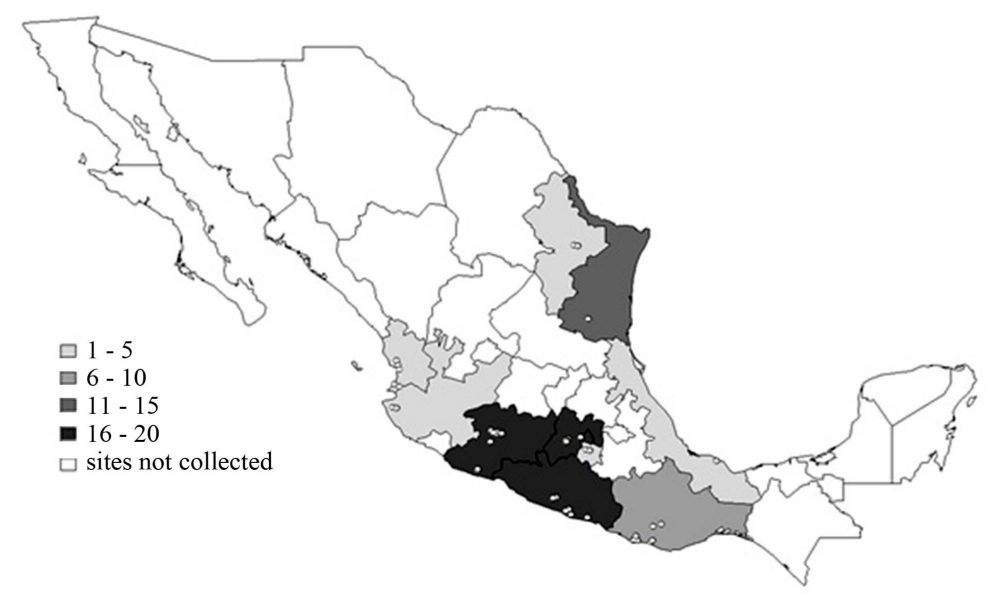

Figure 1. Distribution of collected mice and their frequency to tick-borne rickettsial pathogens in Mexico. 
and blood. The DNA extraction was performed with a DN easy tissue kit (QIAGEN, CA) according to the instructions provided by the manufacturer. We cut $1025 \mathrm{mg}$ of tissue, added $200 \mu \mathrm{l}$ of buffer ATL, and $20 \mu \mathrm{l}$ of proteinase $\mathrm{K}$, mixed by vortexing; and incubated at $55^{\circ} \mathrm{C}$ until the tissue was lysed. We added $200 \mu \mathrm{l}$ buffer AL, and mixed $15 \mathrm{~s}$, and incubated $70^{\circ} \mathrm{C}$ by 10 minutes. Then, we added $200 \mu \mathrm{l}$ of ethanol (99\% - 100\%) and mixed by vortexing. We put the sample in a column and centrifuge by $800 \mathrm{rpm}$, then we put $500 \mu \mathrm{l}$ buffer AW1, and centrifuge by $8000 \mathrm{rpm}$. We added $500 \mu \mathrm{l}$ buffer AW2, and centrifuge $8000 \mathrm{rpm}$ by full speed. And finally, we added $200 \mu$ of AE buffer centrifuge by 1 minute.

\subsection{DNA Preparation}

The DNAs extracted were subjected by primers previously described [12], using species-specific primers. The $16 S$ rRNA gene fragment of all these bacterial was amplificated; except $R$. rickettsii, we used gltA gene. The PCRs were performed as previously described in a total volume of $50 \mu \mathrm{l}$. Each PCR reaction consisted of 2 pmol of each primer, $200 \mu \mathrm{M}$ concentration of each deoxynucleoside triphosphate, PCR buffer, 1 U de Taq DNA Polimerase Recombinat (Invitrogen, Brasil) and 50 to 100 ng of sample DNA for each PCR. PCR products were electrophoresed in 1.5\% agarose gels, stained with SYBR Green (Invitrogen, Brasil), and photographed using a still-video documentation system (Quantum). PCR products were purified with a QIAquick ${ }^{\circledR}$ Gel Extration Kit (QIAGEN, CA). Prevention of cross-contamination and false-negative and false-positive results was managed by using plugged tips, performing PCR in separate room from that used for DNA extraction, and including a negative (water) control in each reaction. A positive control was run for each reaction.

Amplified and purified DNAs were prepared for sequencing using a DyeEx ${ }^{\mathrm{TM}} 3.2$ (QIAGEN, CA) and were sequenced by an automatic sequencer. Sequence data were collected using Chromas lite software (version 2.1.1). Sequence homology search were made via the National Center for Biotecnology Information (National Institutes of Health) BLAST network service. The sequences were aligned initially using DNAMAN.

\section{Results}

A total of 476 rodents (11 genus and 14 species) were collected from 2006 through 2012 from Mexico (Figure 1) and these included different Peromyscus spp. (271), Neotomodon alstoni (71), Reithrodontomys fulvences (60), Microtus mexicanus (21), Megadontomys thomassi (16), Mus musculus (7), Habromys spp. (5), Lyomis iroratus (14), and Neotoma picta (3) and Neotoma 886icketts (4). Species-specific PCR were conducted with DNA samples from rodent of each tick-borne pathogen were: A. phagocytophilum 18 (3.7\%), E. canis 47 (9.6\%), R. rickettsia 15 (2.9\%) and E. chaffeensis 9 (1.8\%) (Table 1). We did a Chi square to looking the risk to Peromyscus spp. And Neotomodon alstoni founding a high relative risk to get positive (Odds ratio 13.7, IC 7.4 - 22.1, $P$-value $<0.01$ and Odds ratio 1.9, IC $1.1-3.8$ and $P$-value $<0.05)$ with $95 \%$ confidence and $\alpha 0.05$, respectively. A total of 89 rodents presented a single infection with 886ickettsial pathogens; 12 presented two pathogens infections that included P. maniculatus, P. leucopus, P. beata, Microtus mexicanus, and Megadontomys; and one Neotomodon alstoni presented a coinfection with three pathogens (Table 2). The positive amplified fragments were sequenced and then analyzed for maximal similarity to other sequences by using BLAST sequence analysis in the GenBank database. Results showed the following homology for each species: $99.9 \%$ with $A$. phagocytophilum (Accession no. KC800983); 99.6\% with E. canis Jake Strain (Accessionno.CP000107); 100\% with $R$. rickettsia (Accession no. KC845924.1) and 100\% with E. chaffeensis (Accession no. NR074500.1).

\section{Discussion}

This study provides data regarding the frequency of R. rickettsii, E. canis, A. phagocytophilum and E. chaffeensis in rodents as host [8] [13]; and Peromyscus species was a very high prevalence of all TBRD pathogens examined, likely showed in others studies with the same frequency of infection [14] [15]. Infections with Ehrlichia and Anaplasma spp. Generally been observed only in a definite range of hosts, including rodents and some large mammals; our studies suggest that several Ehrlichia and Anaplasma spp. Can be transmitted to a variety of host in nature [16]. These data might also provide an opportunity to examine the ecology of emerging zoonoses for which different ecologic determinants for disease transmission may be present [17]. All these diseases are no longer present, mainly because of changes in land, agricultural methods, residential patterns, human's behavior, and vector control; although, tick-borne diseases that may be transmitted to humans from small mammals like 
Table 1. Rodents identifications and PCR results of each tick-borne 887ickettsial pathogens.

\begin{tabular}{|c|c|c|c|c|c|c|}
\hline Identification & & $\mathrm{N}$ & A. phagocytophilum (\%) & E. canis $(\%)$ & R. rickettsii (\%) & E. chaffeensis (\%) \\
\hline \multirow[t]{6}{*}{ Peromyscus } & maniculatus & 76 (15.9) & $2(2.6)$ & 15 (19.7) & $3(3.9)$ & $5(6.6)$ \\
\hline & hylocetes & $2(0.4)$ & $1(50.0)$ & $1(50.0)$ & 0 & 0 \\
\hline & megalops & $37(7.7)$ & 0 & 7 (18.9) & $1(2.7)$ & 0 \\
\hline & beata & $27(5.6)$ & 0 & $2(7.4)$ & $1(3.7)$ & $2(7.4)$ \\
\hline & melanotis & $3(0.6)$ & 0 & 0 & 0 & 0 \\
\hline & lеисориs & $126(26.4)$ & $8(6.3)$ & 0 & $10(7.9)$ & $8(6.3)$ \\
\hline Microtus & mexicanus & $21(4.4)$ & $1(4.7)$ & $1(4.7)$ & $1(4.7)$ & 0 \\
\hline Neotomodon & alstoni & $71(14.9)$ & $2(2.8)$ & $9(12.7)$ & $1(1.4)$ & 0 \\
\hline Reithrodontomys & fulvescens & $60(12.6)$ & $3(5)$ & $7(11.7)$ & $1(1.6)$ & $2(3.2)$ \\
\hline Megadontomys & thomassi & $16(3.3)$ & 0 & $2(12.5)$ & 0 & $1(6.2)$ \\
\hline Orizomys & melanotis & $6(1.3)$ & 0 & $1(16.7)$ & 0 & 0 \\
\hline Lyomis & irroratus & $14(2.9)$ & 0 & 0 & 0 & $1(7.1)$ \\
\hline Mus & musculus & $7(1.5)$ & $1(14.3)$ & 0 & 0 & 0 \\
\hline Habromys & spp. & $5(1.1)$ & 0 & 0 & 0 & 0 \\
\hline \multirow[t]{3}{*}{ Neotoma } & picta & $3(0.6)$ & 0 & 0 & 0 & 0 \\
\hline & mexicana & $4(0.8)$ & 0 & $2(50.0)$ & 0 & 0 \\
\hline & Total (\%) & 476 & $18(3.7)$ & $47(9.6)$ & $18(3.7)$ & 19 (3.9) \\
\hline
\end{tabular}

Table 2. Mixed infections in rodents by PCR results of each tick-borne rickettsial pathogen.

\begin{tabular}{ccc}
\hline Rodents & Mixed bacteria's & Positive rodents \\
\hline Peromyscus maniculatus & A. phagocytophilum/E. canis & 1 \\
& A. phagocytophilum/R. rickettsii & 1 \\
Peromyscus leucopus & E. canis/E. chaffeensis & 3 \\
Peromyscus beata & E. chaffeensis/R. rickettsii & 2 \\
Microtus mexicanus & E. canis/E. chaffeensis & 2 \\
Neotomodon alstoni & A. phagocytophilum/E. canis & 1 \\
Megadontomys thomassi & A. phagocytophilum/E. canis/R. rickettsii & 1 \\
\hline
\end{tabular}

rodents in continue circulating in nature in many parts of the country [7] [12]. Environmental changes may potentially alter the distribution of wild animals and the arthropod vectors and those pathogens they transmit [11]. But demographic and sociologic factors also play a critical role in determining disease incidence. For example, since 1986, rodents from 14 states of United States were found to have been infected with Ehrlichia; and suggest that ehrlichiosis was present in mice at least 12 years before human cases were first recognized. The two main Ehrlichia that cause disease in the United State and animal cycles of the bacteria are likely to exist in areas where human diseases is no yet confirmed [9].

Our results demonstrate that rodents captured in different sites of Mexico were infected with Anaplasma, Eh- 
rlichia and Rickettsia spp. Although infection with Ehrlichia and Anaplasma species have generally been considered to observed only in a defined range of host, including rodents and some large mammals, our studies suggest that several Ehrlichia and Anaplasma species can be transmitted to a variety of host in nature.

Until now, there have not been reports of clinical cases for A. phagocytophilum, and just two reports of $E$. chaffeensis in Mexico, as compared with the numerous reports throughout the word; and has been identified in several vertebrate animals, such as white-tailed deer, dogs, coyotes, and goats, with Amblyomma americanum tick, the most import vector [7]. The loss of large tracts of connected habitat caused by dividing continuous areas into smaller fragments which are isolated from each other, for example through road construction or building development [18]. Fragment size is not only factor defining the community structure of fragment-dwelling organism; in fact it is a functional interaction of numerous factors of the core-zones and edges of patch influenced by the surrounding matrix, habitat area and edge effects [19]. Edges can have negative effects on wildlife due to disturbance, the possible isolation of patches and corridors modifying distribution and dispersal, increasing predation and parasitism; this also involved an elevated risk of human entering tick's habitats [20] and established the wild cycle.

It's important to know if the geographical distribution of positive rodents at TBRD pathogens coincided with a probably of human to get some of these diseases.

\section{Conclusion}

By understanding the mammal cycles by which these tick-borne rickettsial pathogens are established and maintained under natural conditions, it is possible to predict the geographical regions where human populations are at the highest risk for these diseases. These findings also underscore the need for a more comprehensive evaluation of the ecological factors that contribute to the enzootic cycle, including tick, small mammal, and deer populations. With this evaluation, a more comprehensive understanding of the factors that contribute to human's risk and exposure to the potentially fatal, tick-borne pathogens will come. It is imperative to continue the efforts to identify additional tick-borne pathogens to further disclose the extent and the possible public health significance of these agents.

\section{Acknowledgements}

This project was supported by CONACYT (Grants 1999-30694 and 2008-1 87868); FIS/IMSS 2013 G13/1192. CS received a Scholarship for Doctorate studies from CONACYT, Mexico.

\section{References}

[1] Chapman, A.S., Bakken, J.S., Folk, S.M., Paddock, C.D., Bloch, K.C., Krusell, A., et al. (2006) Diagnosis and Management of Tick-Borne Rickettsial Diseases: Rocky Mountain Spotted Fever, Ehrlichioses, and Anaplasmosis-United States. MMWR Recommendations and Reports, 31, 1-27.

[2] Sosa-Gutierrez, C.G., Quintero, M.T., Gaxiola, C.S., Cota, G.S., Esteve-Gassent, M.D. and Gordillo-Perez, M.G. (2013) Frequency and Clinical Epidemiology of Canine Monocityc Ehrlichiosis in Dogs Infested with Ticks from Sinaloa, Mexico. Journal of Veterinary Medicine, 2013, Article ID: 797019. http://dx.doi.org/10.1155/2013/797019

[3] Danta-Torres, F., Chomel B.B. and Otranto, D. (2012) Ticks and Tick-Borne Diseases: A One Health Perspective. Trends in Para, 28, 10.

[4] Kim, C.M., Yi, Y.H., Yu, D.H., Lee, M.J., Cho, M.R., Desai, A.R., Shringi, S., Klein, T.A., Kim, H.C., Song, J.W., Baek, L.J., Chong, S.T., O’Guinn, M.L., Lee, J.S., Lee, I.Y., Park, J.H., Foley, J. and Chae, J.S. (2006) Tick-Borne Rickettsial Pathogens in Ticks and Small Mammals in Korea. Applied and Environmental Microbiology, 73, 57665776.

[5] Gordillo-Pérez, G., Vargas Sandoval, M., Sosa-Gutiérrez, C.G., Minero-González, E., Shroeder, E., Montiel, G., Guzmán-Cornejo, C., Sánchez, V. and Torres-López, J. (2012) Prevalencia de Infección de Borrelia burgdorferi y Ehrlichia spp. en Garrapatas y Roedores Provenientes de tres Parques Nacionalesdel Centro de la República Mexicana. In: de Postgraduados, C., Revista Acarologia Latinoamerica, Acarología Latinoamericana, Estado de México, 291-295.

[6] Feria-Arroyo, T.P., Castro-Arellano, I., Gordillo-Perez, G., Cavazos, L., Vargas-Sandoval, M., Grover, A., Torres, J., Medina, R.F., Pérez de León, A. and Esteve-Gassent, M.D. (2014) Implications of Climate Change on the Distribution of Thetick Vector Ixodesscapularis and Risk for Lymedisease in the Texas-Mexicotransboundary Region. Parasites \& Vectors, 7, 199. doi:10.1186/1756-3305-7-199. http://dx.doi.org/10.1186/1756-3305-7-199

[7] Walker, D.H., Paddock, C.D. and Dumler J.S. (2008) Emerging and Re-Emerging Tick-Transmitted Rickettsial and 
Ehrlichial Infections. Medical Clinics of North America, 92, 1345-1361. http://dx.doi.org/10.1016/j.mcna.2008.06.002

[8] Parola, P. and Raoult, D. (2001) Ticks and Tick-Borne Bacterial Diseases in Humans: An Emerging Infectious Threat. Clinical Infectious Diseases, 32, 897-928. http://dx.doi.org/10.1086/319347

[9] Gubler, D., Raiter, P., Ebi, K., Yap, W., Nasci, R. and Patz, J. (2001) Climate Variability and Change in the United States: Potential Impacts on Vector and Rodent-Borne Diseases. Environmental Health Perspectives, 102, 223-233. http://dx.doi.org/10.2307/3435012

[10] Illoldi-Rangel, P., Rivaldi, C.L., Sissel, B., Fryxell, T., Gordillo-Perez, G., Rodriguez-Moreno, A., Williamson, P., Montiel-Parra, G., Sanchez-Cordero, V., and Sarkar S. (2012) Species Distribution Models and Ecological Suitability Analysis for Potential Tick Vectors of Lyme Disease in Mexico. Journal of Tropical Medicine 2012, Article ID: 959101. http://dx.doi.org/10.1155/2012/959101

[11] Chae, J.S., Yu, D.H., Shringi, S., Klein, T.A., Kim, H.C., Chong, S.T., Lee, I.Y. and Foley, J. (2008) Microbial Pathogens in Ticks, Rodents and a Shrew in Northern Gyeonggi-Do near the DMZ, Korea. Journal of Veterinary Science, 9, 285-293. http://dx.doi.org/10.4142/jvs.2008.9.3.285

[12] Sosa-Gutierrez, C.G., Vargas, S.M., Torres, J. and Gordillo-Pérez, G. (2014) Tick-Borne Rickettsial Pathogens in Ticks from Mexico. Tick and Tick-Borne Diseases Journal, TTBDIS-D-14-00093, in Submitted.

[13] Foley, J.E., Nieto, N.C., Adjemian, J., Dabritz, H. and Brown, R. (2008) Anaplasma phagocytophilum Infection in Small Mammal Host of Ixodes Ticks, Western United States. Emerging Infectious Diseases Journal, 14, 1147-1150. http://dx.doi.org/10.3201/eid1407.071599

[14] Walls, J., Greig, B., Neitzel, D. and Dumler, S. (1997) Natural Infection of Small Mammal Species in Minnesota with the Agent of Human Granulocytic Ehrlichiosis. Journal of Clinical Microbiology, 35, 853-855.

[15] Gordillo-Perez, G., Vargas, M., Solorzano-Santos, F., Rivera, A., Polaco, O.J., Alvarado, L., Muñoz, O. and Torres, J. (2009) Demonstration of Borrelia burgdorferi sensu stricto Infection in Ticks from the Northest of Mexico. Clinical Microbiology and Infection, 15, 496-498. http://dx.doi.org/10.1111/j.1469-0691.2009.02776.x

[16] Satta, G., Chisu, V., Cabras, P., Fois, F. and Malasa, G. (2011) Pathogens and Symbionts in Ticks: A Survey on Tick Species Distribution and Presence of Tick-Transmitted Microorganisms in Sardinia, Italy. Journal of Medical Microbiology, 60, 63-68. http://dx.doi.org/10.1099/jmm.0.021543-0

[17] Williamson, P.C., Bullingsley, P.M., Teltow, G.J., Seals, J.P., Turnbough, M.A. and Atkinson, S.F. (2010) Borrelia, Ehrlichia and Rickettsia spp. in Ticks Removed from Persons, Texas, USA. Emerging Infectious Diseases, 16, 441-446. http://dx.doi.org/10.3201/eid1603.091333

[18] Watling, J.I. and Donnelly, M.A. (2006) Fragments as Islands: A Synthesis of Faunal Responses to Habitat Patchiness. Conservation Biology, 20, 1016-1025. http://dx.doi.org/10.1111/j.1523-1739.2006.00482.x

[19] Vogt, P., Riitters, K.H., Estreguil, C., Kozak, J., Wade, T.G. and Wickham, J.D. (2006) Mapping Spatial Patterns with Morphological Image Processing. Landscape Ecology, 22, 171-177. http://dx.doi.org/10.1007/s10980-006-9013-2

[20] Allan, B.F., Keesing, F. and Ostfeld, R.S. (2003) Effect of Forest Fragmentation on Lyme Disease Risk. Conservation Biology, 17, 267-272. http://dx.doi.org/10.1046/j.1523-1739.2003.01260.x 
Scientific Research Publishing (SCIRP) is one of the largest Open Access journal publishers. It is currently publishing more than 200 open access, online, peer-reviewed journals covering a wide range of academic disciplines. SCIRP serves the worldwide academic communities and contributes to the progress and application of science with its publication.

Other selected journals from SCIRP are listed as below. Submit your manuscript to us via either submit@scirp.org or Online Submission Portal.
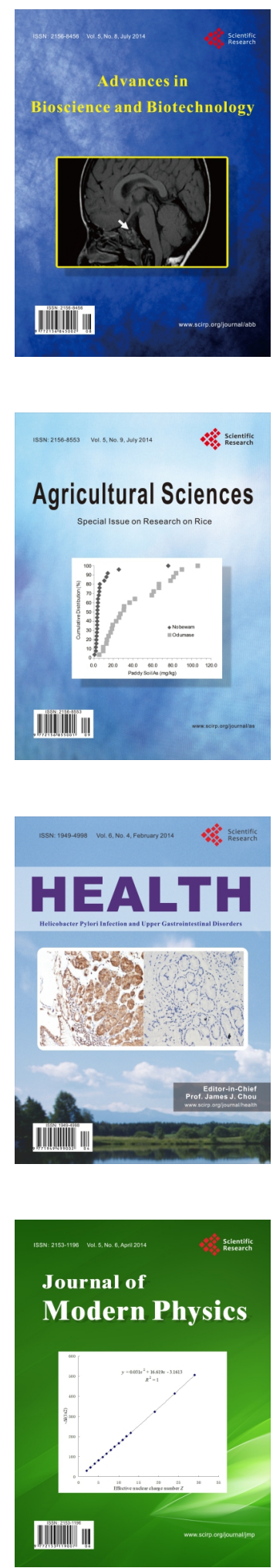
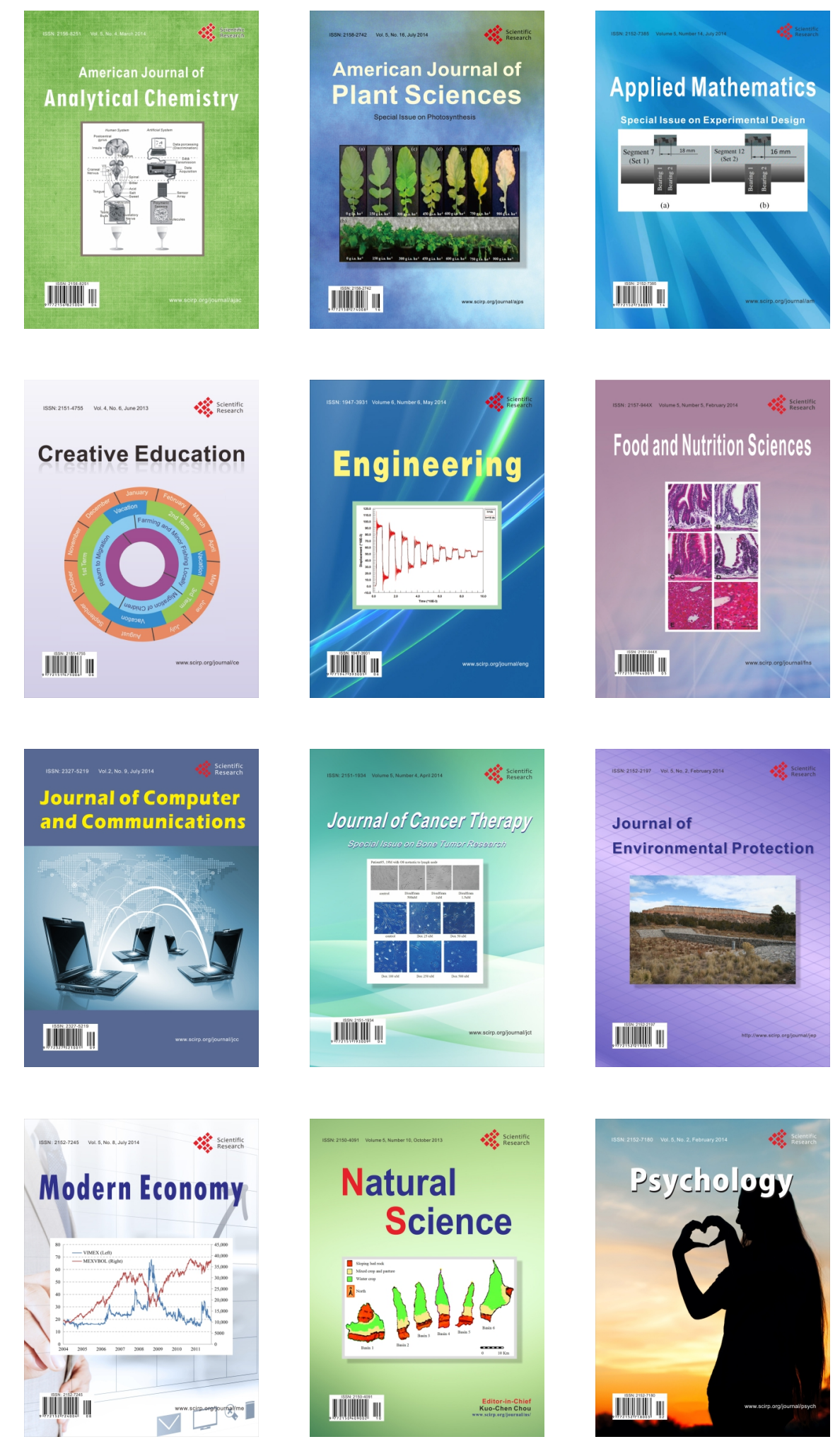